\title{
Exploring Changes in Teachers' Instructional Practice through Self-evaluation as a Meditational Activity: A Case Study
}

\author{
Umi Tursini \\ English Education Department, University of Kanjuruhan Malang, East Java, Indonesia
}

\begin{abstract}
This study investigated an Indonesian English language teacher's instructional practice and the extent to which the practice capable of change as a result of engagement in mediated self-evaluation. The study was framed using Vygotsky's sociocultural theories. A case study, which drew on multiple data sources including interviews, classroom observations, and documentation, was employed. A range of artefacts including lesson video recording, student feedback, and collegial dialogue are used to self-evaluate teacher's instructional practice. The qualitative analysis suggested that self-evaluation involving teacher's self-reflection on teaching in Indonesian university contexts had significant potential for mediating changes in instructional practice. The findings also revealed that teacher self-evaluation led to heightened self-reflection through which teachers understood themselves and their instructional practice more deeply in terms of their strengths and areas for development. This suggests that teacher self-evaluation contributes to professional learning by empowering teachers to transform their practice. Given that teacher self-evaluation is still a relatively new phenomenon in the Indonesian educational context; the positive outcomes reported in this study are promising. Hence, it is reasonable to recommend that educational leaders in Indonesia provide opportunities for teachers to formally self-evaluate. The necessary provisions must therefore be in place and will ideally include formal training or workshops on how to perform a self-evaluation, the allocation of time to carry out the process, and ongoing support to address teachers' needs and concerns about the process in terms of consistency and timeliness.
\end{abstract}

Index Terms-instructional practice, self-evaluation, meditational activity, sociocultural theory, English language teacher, case study

\section{INTRODUCTION}

Teacher evaluation is an issue in a range of international contexts and is linked to growing global concerns with quality and accountability in education. Evaluations of teacher professionalism (English teachers included), course structure and delivery, and teacher performance occur in universities in Indonesia by way of summative processes. They include student questionnaires completed at the end of each semester. Unfortunately, there are limitations inherent to this evaluation method including misunderstandings on the part of students when answering questions, the subjectiveness of the responses, and a feeling of reluctance by some students to provide accurate and honest feedback for fear of recrimination.

Moreover, teachers receive the questionnaire results - usually towards the end of the semester - in Likert Scale form without sufficient or specific descriptions or information about what teaching actions should be maintained or improved upon during the term. Many teachers therefore do not use the questionnaire results as resource to guide teaching improvement and personal development. Moreover, student feedback alone has insufficient detail to help teachers improve and, in any event, this evaluation method is only used by the institution for the purposes of a performance review (Wesner, 2007). As a result, a great number of English teachers in Indonesia are dissatisfied with this summative evaluation method (Limantoro, 2003). For most teachers, evaluations conducted by department heads do not help them to improve their teaching practice as they are generally brief, lack specific suggestions for improvement, and lack the provision of resources needed to improve (Airasian \& Gullickson, 1997). Furthermore, there is limited discussion at teachers' meetings about classroom practices and teaching performance (Bjork, 2005). As a consequence, teachers have to rely on their own initiative if they wish to improve their teaching expertise and to engage in professional development.

From a sociocultural theoretical perspectives, "human cognition is understood as originating in and fundamentally shaped by engagement in social activities" (Johnson \& Golombek, 2011, p. 2). Teachers acting as individuals in sociocultural contexts learn how to improve their teaching skills by participating in particular professional development activities. Teacher self-evaluation is one such activity that helps English teachers in Indonesia to undertake self-learning in order to develop their teaching practice. Teacher self-evaluation is a process whereby teachers gather data on their own teaching effectiveness. The data is then analysed in order to reflect on what changes may be required to facilitate improvement (Taylor, 1994). Teacher self-evaluation is therefore a form of self-reflection and improvement which 
becomes one of essential indicators of teacher quality. Teacher self-reflection and improvement have been one of major focuses of the education reforms in Indonesia (Chang et al., 2014, p. 44). Throughout teacher self-evaluation processes, teachers are not only the object of classroom observation; they are also active participants collecting information on their own teaching practices. Teachers are central to the self-evaluation process as they are responsible for determining the appropriate timing and form of the evaluation, as well as for organising, examining and interpreting the data to facilitate improved effectiveness.

Within Vygotskian sociocultural theory, mediation is a central concept (Lantolf \& Thorne, 2006) explaining how humans utilise cultural tools in order to undertake activities. The self-evaluation process requires teachers to use particular mediational tools for self-reflection including journals or diaries, self-reporting inventories or checklists, and audio or video recordings of a lesson (Richards \& Lockhart, 1996). Teacher self-evaluation tools proposed by Airasian and Gullickson (1997) include teacher self-reflection questions, media recording and analysis, student feedback tools, teacher portfolios, student performance data, external or peer observations, journaling, and collegial dialogue involving sharing experience and joint problem solving. Teachers are thus encouraged to use tools applicable to their teaching context in accordance with their affordances and constraints.

Given teacher self-evaluation has only recently been introduced into the Indonesian educational context, this study comprises a case study involving one English language teacher, Maya (a pseudonym). The teacher was invited to video record her teaching and learning processes, obtain student feedback on her teaching, and participate in collegial dialogues as a series of teacher self-evaluation activities. This study was guided by the following research questions:

1. What is the nature of Maya's instructional practice?

2. To what extent is Maya' instructional practice capable of change as a result of engagement in mediated selfevaluation?

\section{METHODOLOGY}

This study comprises a case study design that is exploratory and descriptive in nature to arrive at basic information (Merriam, 2009). A single case in this study is explored and understood in depth to learn about its "self centring, complexity, and situational uniqueness" (Stake, 2006, pp. 6-7).

\section{A. The Participant}

Maya, a 32-year-old female, is an English teacher who has been teaching English for more than ten years. Her professional experiences range from teaching pronunciation, speaking, and listening at university level, to being a private teacher for elementary and junior high school students while an undergraduate student at a well-known public university in Malang. During the semester in which this research was undertaken, Maya was pursuing a Master's degree at the same university.

\section{B. Data Collection}

In this study, different instrument types were used for data collection to facilitate the acquisition of reliable data to best answer to the research questions and to increase the quality of the study. The instruments chosen for data collection in this study were interviews, direct field observations/lesson video recordings, and documentation. The data collection process is illustrated in Chart 1 below.

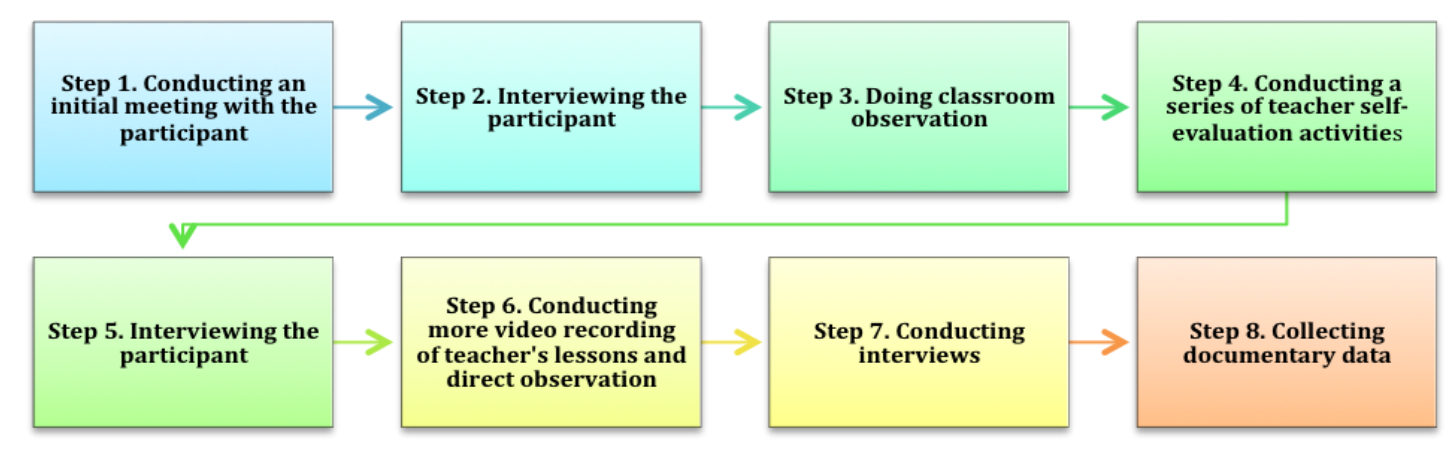

Chart 1: Overview of data collection process

The initial step in the first data collection phase involved conducting a meeting with the participant. The second step involved conducting the first semi-structured interview with the participant. This interview had a biographical focus and aimed to gather background information on the participant's historical life experiences (including her educational background and teaching experiences), and activities to improve her professional practice. The third step in the data collection process was the first observation of participant's lesson. The observations focused on the teacher's instructional practices including the way she taught, talked to or interacted with the students, as well as the way in which she managed the class prior to their engagement in a series of teacher self-evaluation activities. 
Participant then engaged a series of teacher self-evaluation activities as the fourth step in the data collection process. The activities included assisting the participant to videotape her teaching practices on two separate occasions; administering student feedback questionnaire to students immediately following the lesson; inviting the participant to individually explore the content of the video recorded lesson and student feedback forms; and inviting the participant to take part in collegial dialogues.

The fifth step was to conduct the second interview of participant following her participation in the teacher selfevaluation activities. She then was invited again to video record her teaching practices during a lesson so that she could later reflect upon her practices in a series of teacher self-evaluation activities. The researcher also observed the lessons and observation notes were recorded.

The eighth step in the process was to conduct unstructured interviews with the case study teacher. The final interview was conducted to primarily to obtain comments, ideas, and feedback from the participant regarding the teacher selfevaluation activities and her thoughts about making changes in their teaching practices. Furthermore, unstructured interview was conducted with the study teacher, which included questionings about the observed lesson, or other matters to emerge from analyse of the video recorded lessons.

The analysis of data in this study was conducted according to an eight-step process: (1) transcribing and translating all interviews; (2) referring to research questions; (3) identifying evidence addressing the research question; (4) referring to theoretical frameworks; (5) drawing tentative conclusions; (6) confirming tentative conclusions from other evidence; and (7) repeating step 2 to 6.

\section{RESULTS}

The findings of this study comprise four discussions: (1) Maya's background; 2) Maya's initial instructional practice; 3) productive disruptions resulting from teacher self-evaluation as a mediational activity; and 4) changes in Maya's instructional practice.

Maya's Background

After teaching for several years, Maya realised that she enjoyed working as a teacher because it provides her with the opportunity for on-going learning. She asserted:

Initially, I did not want to be a teacher, but then I changed my mind. I know now that by teaching I receive many things. Teaching is a learning process for me. Before teaching, I have to learn and prepare first so that I will be ready to teach. Being teacher also requires me to dig more knowledge.

Maya's ways to improve her professionalism are by reading English books, watching English movies, sharing ideas and practices with her colleagues informally to develop new teaching methods, and joining an academic workshop at least once per semester. She points out that joining the academic workshops assists her to acquire new information about interesting class activities to apply in her English class to help the students to enjoy the class. Maya mentioned that her friends who are novice English teachers sometimes join her class to observe her teaching practices in order to learn how to teach more effectively. As such, Maya is considered to be an experience teacher by her friends.

Teacher self-evaluation was something new to Maya. By participating in this study, Maya has video recorded her lessons for the first time, asked for student feedback on her teaching, and participated in collegial dialogues. Previously, the only evaluation of her teaching she had undertaken was to share her thoughts and concerns informally with her colleagues. Maya said, "I sometimes talked with my friend informally. They suggested me to use certain methods or materials because those worked for them". As such, Maya already recognised the value of sharing her ideas about teaching with her colleagues in order to develop different teaching methods to implement in her lessons.

Maya's initial instructional practice

Maya's instructional practice was considered in relation to her dialogue and actions as a teacher as well as her statements during the interviews. Two aspects of Maya's instructional practice which (consciously or unconsciously) shaped her teaching actions were: (1) dominance and (2) formality and distance.

Maya dominated the class

The findings showed that Maya had the tendency to be dominant in her class. This included having a control over the students' learning, high levels of teacher talking during her class, and nominating which students answer her questions. Maya's lesson was monologic rather than interactive in that she spoke much more than the students during the lessons. In one class meeting, Maya spoke for the majority of the time during one lesson, telling the students what to do, explaining the topic, and discussing and guiding the activities. She did not require a high level of student participation during lessons and the students did not have the opportunity to interact with each other during the teaching and learning process. She also did not provide the students with an opportunity to ask questions, for example after she finished explaining how to engage with the lesson materials. Students passively received the information/knowledge from her and only spoke up if Maya ask them to do so.

Maya often asked the students to participate in the class activity by nominating which students were to answer the questions, as demonstrated in the following excerpt taken from a recording of one of her lessons:

[Before continuing her discussion to a new topic, Maya asks some warm up questions to the students]

MAYA: Okay now I will ask you some questions before we move on to listening 1. You said that you have good friends right? Are your friends different from you? I mean in the characteristics. Let's say your friends are ... what is it 
... funny, and then easy going and then ... what is it ... like jokes and you maybe are quite serious so you and your friends are different. Okay. What about you? [Looking to a student]

BUDI: Different

MAYA: Different [repeating Budi's answer]. Tell us what make you different.

BUDI: My friend is so quiet person, but I'm talkative.

MAYA: Okay. What about you? (looking to a student)

INDAH: I'm serious, loyal, but my friend is not serious, funny, and easy going.

MAYA: Okay. You're serious and loyal and your friend is not serious.

As in the above excerpt, Maya limited the opportunities for the student to participate or answer voluntarily in the class by nominating students to answer her questions. Her instruction; what about you? was an indication of her intention to control student participation in the class. In addition, in reference to classroom discourse, the above excerpt showed Maya demonstrated the minimum interaction pattern by implementing the initiation-response-follow-up (IRF) pattern proposed by Sinclair and Brazil (1982). Most of the time, Maya initiated a question, the students responded, and Maya then provided feedback on the response. An example taken from the above excerpt was:

Initiation: What about you?

Response: My friend is funny and easy going, but I'm serious person.

Feedback: Okay. Your friend is funny and you're a serious person

The example indicated that Maya dominated the interaction because the type of feedback she provided to the students was repetitive, and she did not provide the third turn to facilitate further opportunities for interaction. This interaction pattern minimised the students' productive thought and further participation in classroom activities.

Maya acted formally and made distance with her students

The findings also showed that Maya tended to be formal and made distance with her students in her teaching practice. This manifested through the discouraging comments she often made to the students, her tendency to not refer to the students by name when interacting with them, and by the fact she seldom complimented the students. The following excerpt is an example of Maya's instructional practice that reveals her tendency to be formal through the way she acts and talks to the students in the listening class. In particular, it demonstrates how Maya makes discouraging comment to the students:

[After Maya plays the conversation, discusses and explains the answers with the students, she then asks some referential questions relating to topic of discussion by pointing to certain students to answer. The topic for the lesson is "good friend"].

MAYA: Still talking about good friends. What do you usually do when you have free time with your friends? [pointing to Siska]

SISKA: Talking about our future

MAYA: You talk about future [repeating Siska's answer]. So you have chat. Okay. Is it really activity you do?

SISKA: Yes.

MAYA: Okay. You never go out somewhere?

SISKA: No.

MAYA: Never. What about you? [pointing to Sita] You please. Yes, you sitting in the middle.

SITA: [Remains silent]

MAYA: Do you have good friends?

SITA: [Remains silent]

MAYA: Do you have good friends? [raising her voice] Do you have good friends? Yes or no?

SITA: Yes.

MAYA: Yes. What do you usually do with your friends?

SITA: [Smiling and remaining silent].

MAYA: I need your answer not your smile [again, raising her voice]. Okay. Mas, please [pointing to Ahmad]. Do you have good friends?

AHMAD: Yes. Sometimes I'm talking about our lesson in the library and in the canteen and sometimes just kidding.

The above excerpt presents some clear actions that reveal Maya's tendency to be formal. Maya again made a discouraging comment by saying; "I need your answer not your smile" to Sita when she did not answer her question. It appears to be the case that the student was finding it difficult to express her idea in English, especially when the entire class was waiting for her answer. She therefore just smiled and did not answer Maya's question. However, Maya did not tolerate this response and made a discouraging comment. Maya seems not aware of the impact her verbal language may have on the students' motivation. Such comments are likely to have a detrimental effect on the responding student in particular but also on all of the students in general, further limiting their involvement in class activities. The above excerpt also shows that Maya rarely mentioned the student's names while interacting with them. She referred to the students as "you" or sometimes pointed them with her finger if she wanted a student to answer. This implies that Maya was either not familiar with the students' names or did not feel the use of names was important.

Productive disruptions resulting from teacher self-evaluation as a mediational activity

As mentioned before, the research participant was supported to utilise three teacher self-evaluation instruments: 
lesson video recording, student feedback, and collegial dialogue. When asked her opinion about the use of video recording to evaluate teaching practices, Maya said, "it was great. It was like a mirror to see myself, to see my teaching". Hence, the video recording of Maya's lessons provide a platform for her to see herself and her teaching practices from a new perspective.

When Maya was asked about the use of student feedback, Maya asserted, “on one side I'm happy, but on the other side I'm not. I'm happy because I got some good comments from my students, but then I could not get more information about what I should improve". That is, the students did not provide sufficient information to Maya regarding her teaching limitations as the students provided mostly favourable comments on her teaching. This may have been because the students were satisfied with Maya's teaching practices or more likely, because they did not have enough courage to say something negative about her teaching for fear of reprisal. The students might be afraid if they provide negative feedback on Maya's teaching, they could not get good grade in their subject. However, student feedback still contributed valuable insights into Maya's teaching practices.

Maya also felt that collegial dialogue helped her to improve, as suggested in the comment, "participating in collegial dialogues makes me a better teacher. I can improve my teaching methods and techniques by sharing with my colleagues, especially if we teach the same subjects". In other words, Maya recognized the affordances of each mediational tool she has used as a means to identify the aspects that promote or hinder the development of her professional practice.

Specifically, a series of teacher self-evaluation activities provide Maya with some productive disruptions. These productive disruptions challenged or disrupted her usual thoughts about her teaching practice, as well as, about herself as a teacher. The productive disruptions were: (1) how Maya saw herself as a person; and (2) how Maya saw her teaching. The first productive disruption is related to professional identity which is defined as a "personal thing that indicates how one identifies with being a teacher and how one feels as a teacher" (Mayer, 1999, p. 7). Video recording Maya's lesson functioned as a powerful mediational artefact for Maya to learn about herself and to assist her to realise that she was not a warm and friendly teacher to the students, but rather that she was critical and judgmental. She admitted, "after viewing my lesson video recordings, I feel a kind of shock. I admit that I'm less friendly and sometimes judgmental to my students". Maya became more aware fully of her tendency to be formal/distant. After reflecting on her practice, Maya gained new insights into her professional identity, a key aspect of which was her tendency to be formal/distant.

The next productive disruption Maya experienced as a result of her engagement in a series of teacher self-evaluation activities relates to the new perspectives she develops in relation to her teaching. Firstly, Maya realised that she presented a monotonous teaching style in her listening class. Maya already felt that her teaching lacked in variety and interest. After watching the video recording of her teaching practices, considering her responses to the teacher selfreflection questions, and reading the student feedback on her teaching, Maya had concrete data that her teaching was indeed monotonous. She remarked, "some students said that my class was boring. When I viewed my teaching in the video, I agreed with them".

Secondly, Maya realised that she seldom gave compliments to the students. The video recording and student feedback used as mediating artefacts during the teacher self-evaluation activity provided Maya with an opportunity to 'know' her teaching style. This revealed to her that she was too serious during lessons and that she needed to establish a better relationship with the students by praising them more often and by referring to them by their names. Maya pointed out, "I saw myself in the taped-performance and I found my weakness. I couldn't see myself praising my students".

Thirdly, the range of teacher self-evaluation instruments used by Maya to evaluate her teaching allowed her to realise that she needed to change the way she interacted with the students. She declared, "I need to improve my classroom interaction. I tended to ask to some active students and ignore the ones who were passive".

Changes in Maya's instructional practice

\section{A. Change in Her Class Dominance Practice}

The productive disruption in Maya's teaching practice and her identity as a teacher as a result of mediated selfevaluation encouraged her to imagine her future identity as an English teacher. A comparison of Maya's teaching practices in the video recording of her lesson before the self-evaluation activity with her teaching practices in the video recording after the self-evaluation shows a significant difference in Maya's identity and expression as teacher. Maya transformed into a more 'democratic" teacher. She does not try to exercise too much control over the students' learning, she reduces the amount of time she spends talking during lessons by inviting the students to be more active participants in classroom discussions, and she provides more opportunities for the students to ask and answer questions voluntarily.

Maya's change in her class dominance practice was greatly influenced by her engagement in collegial dialogues. The collegial dialogues provide Maya with opportunities to hear from other teachers how she might address the limitations in her teaching practices. By sharing her thoughts about the monotonous nature of her teaching with her colleagues, they were able to provide suggestions on how to use a greater variety of teaching materials during her listening classes. Maya's awareness of her teaching limitations and her inability to resolve her issues alone encouraged to make use of collegial dialogue as a mediating tool in order to facilitate her development.

Maya decided to use more interesting teaching materials than simple pre-recorded cassettes. In addition to the use of the textbook, Listen Carefully, Maya also selected various videos from YouTube and the British Council for use. Some were authentic listening materials and others were adapted for listening classroom. The students now had their own 
computer with headsets to watch the videos. Maya's teaching was reorganised to make it more varied including the introduction of the following practices: brainstorming activities emerging from referential questions provided to the students related to the discussion topic; introducing and discussing difficult vocabulary items in the video as preactivities; playing the video and discussing the content; and answering questions related to the video as a post-activity. The brainstorming activity helped Maya to generate greater student interaction and to provide students with more opportunities to express their ideas in English. This is evidenced in the excerpt below taken from a recording of Maya's lesson:

[The topic for listening class will be "Going Abroad". Maya asks some referential questions before she comes to the discussion topic]

MAYA: Do you have a plan to go abroad?

SANTI: Yes to German.

MAYA: Germany? Why Germany?

SANTI: Because I want to meet national team football.

MAYA: Football national team.

SANTI: Yes, football national team and I want to visit all cities.

MAYA: Okay, so you want to visit all cities in Germany. So you love Germany?

SANTI: Yes ma'am.

MAYA: Okay, how about others? [Chorifa raises her hand] Yes, Chorifa, where do you want to go?

CHORIFA: Singapore.

MAYA: Why?

CHORIFA: I want to visit Universal Studio.

MAYA: Only that place?

CHORIFA: I also want to visit Sentosa Island and Singapore Zoo.

As the above excerpt illustrates, Maya invited the students to express their ideas in English by asking a referential question, that is a question that has no specific answer and is used to encourage genuine communication. Furthermore, an analysis of the classroom discourse shows that rather than making evaluative comments, Maya provides an interactive type of feedback to expand or modify the students' response. This is apparent when she replies to the students: "Germany? Why Germany?", "Why" and "Only that place?" In other words, Maya does demonstrate the minimum IRF interaction, but uses the third turn to invite further opportunities for the students to practice the target language. This is because the IRF pattern promotes further interaction more effectively if the teacher employs the third turn to facilitate further opportunities for interaction rather than using evaluative feedback (Walsh, 2002). In addition, in the above excerpt when Maya asks, "how about others?" she does not nominate which students answer her question. Instead, she lets the students answer voluntarily. This implies that Maya has become more "democratic" and less "dominant" as a teacher.

Data from the video recording of Maya's lessons conducted after she engaged in a series of teacher self-evaluation activities also demonstrates that she does not try to exercise too much control over the students' learning. She not only employs more interesting teaching activities, she also listens to what the students want in the class activities. Moreover, she then asks students for their opinion about the teaching material she has provided.

The video data also shows that Maya reduces the amount of time she spends talking by inviting the students to be more active in the classroom discussion. She prefers to address the questions to entire class, as shown in the excerpt below:

MAYA: How can the man get to the office?

STUDENTS: On foot!!! [entire class is answering all together, loudly and enthusiastically]

MAYA: Okay, on foot. How long does it take?

STUDENTS: 20 minutes!!! [again, entire class is answering all together, loudly and enthusiastically]

MAYA: Yes 20 minutes. And what time he needs to go from the hotel?

STUDENTS: 9.30.

MAYA: Okay, 9:30. Great!

As evidenced in the above excerpt, Maya discusses some questions related to the conversation she previously played to the students and they answer her questions eagerly. This eagerness suggests that the atmosphere in Maya's classroom is more relaxed and that the students now want to actively participate in the classroom discussion. In addition, Maya provides more opportunities to the students to ask questions following her explanation and discussion of the topic. "That's all from video, do you have questions?" is an example of how she invites the students to participate.

Maya utilises the whiteboard to explain the learning material to the students more often following the move to the multimedia laboratory. This technique helps the students to understand her explanations. Overall, the atmosphere of her class is more relaxed and enjoyable and as a result many students are active in the teaching and learning process. They are enthusiastic to answer Maya's questions. Maya commented., "I changed my teaching strategy after engaging in teacher self-evaluation activity to have better teaching so that my students can understand what I explain and get what they want and I want in that teaching". In other words, teacher self-evaluation functioned as a mediational activity to direct Maya's thinking to implement more interesting and engaging teaching and learning practices. Vygotsky argued 
that culturally constructed and organised means mediate human consciousness (Lantolf \& Thorne, 2006, p. 60).

\section{B. Changes in Maya's Formality/Distance Practice}

Data from the video recording of Maya's lessons - conducted after she participated in a series of teacher selfevaluation activities - her interview responses, and researcher observation notes suggest that Maya has transformed herself into a friendlier teacher who has a more positive relationship with the students. In this sense, Maya's engagement in a series of teacher self-evaluation activities helped her to change her formality/distance practice and transform her identity as a teacher and her teaching practice. Maya no longer makes discouraging comments to the students, she refers to them by their names, and she often compliments to the students on their work.

When Maya asks a student to answer a question and the student remains silent, rather than making a discouraging comment, Maya is more willing to provide the student with more time to provide an answer as illustrated in the excerpt below:

[After listening to a recorded conversation, Maya asks some questions related to the content]

MAYA: What excuse do they decide to use? [A student, Putri, seems want to answer] What is it? Putri?

PUTRI: Hmm ... repeat please.

MAYA: Do you want me to repeat it? Okay then [replaying the conversation in the video].

MAYA: Yes, Putri? [waiting for an answer]

PUTRI: [Keeping silent for some time].

MAYA: Or others can help?

ALL STUDENTS: [keeping silent for quite long time].

MAYA: What excuses do they decide to use finally? [a student, Edo, wants to answer] Yes Edo?

EDO: Ehm ... prior engagement.

MAYA: Prior engagement? Excellent, that's the excuse they finally use.

As in the above excerpt, Maya displays greater patience towards the students when seeking a response. When she directed a question to Putri, who asked Maya to replay the conversation, Maya acknowledged Putri's request by replaying the conversation. After providing Putri with adequate time to answer her question, and when an answer was still not forthcoming, Maya then directed her question to another other student. This teaching action demonstrates how Maya has become more patient, sensitive, and responsive to the students. The above excerpt also reveals that Maya is familiar with the students' names (e.g. Putri and Edo). Although Maya still predominantly responds to a correct answer from the students with the expression, "okay", she also includes other forms of praise towards students who are able to answer her questions correctly. One such example is her use of the expression, "excellent", "very good" and "well done".

Another change in Maya's teaching behaviour is her use of the students' names when interacted with them. For example, she refers to the students by name (e.g., Wihelmina, Rohmat and Florence) when she asks them to answer her questions. Maya shows she is familiar with the students' names and starts to use this knowledge to facilitate a higher quality level of interaction with them (rather than use the expression, "You"). Using the students' names during the interactive process demonstrates to the students that Maya recognises them as individuals and this enables Maya to establish a stronger teacher-student relationship. As a result, there is an increase in the level of student participation in the class activity.

Further evidence that demonstrates how Maya has changed her formality/distance practice is her intention to occasionally include joke-telling into her teaching practice. An example of this is provided in the excerpt below:

[The discussion topic of the lesson is personal profile and Maya is asking relatively personal questions to the students including Edo whose hair is coloured red]

MAYA: Mention your name and your phone number.

EDO: Edo, I'm Edo and my number is 4857558846226

MAYA: Okay. Where are you from?

EDO: Samarinda

MAYA: Oh from Samarinda. I thought you're from America because your hair is red [students laugh].

In the Indonesian context, it is uncommon to see a person with coloured hair as most Indonesians have dark hair. When Maya said, "I thought you're from America because your hair is red" in response to the student's answer, she once again displays her sense of humour to the class and this invites the students to laugh.

\section{DisCUSSIONS}

Overall, the findings illustrate that after engaging in teacher self-evaluation as a mediational activity, Maya's teaching practice is no longer driven by formality/distance practice. Maya has transformed into a friendlier teacher who establishes a better relationship with the students. Maya agreed: "I now have a more intense interaction with my students. I always try to be their friend so that they will feel comfortable to interact with me". When asked about how teacher self-evaluation helped her, Maya asserted:

What I can learn from the teacher self-evaluation activity is that I can see myself when I was teaching. I then have a kind of reflection like I should do this should do that, trying to be better. I'm trying to be better, especially to give 
compliments to my students though it's not easy because I always forget to do that.

The above statements imply that the process of self-evaluation has helped Maya to reflect on her teaching practices to identify what aspects need to improve. As stated previously, teacher self-evaluation 'disrupts' Maya's identity as a teacher as well as her perspective of her teaching practice. These productive disruptions lead Maya to reflect upon her teaching which in turn leads her to understand that her identity limits her fit in her field and that a new identity needs to be developed. This is in line with Beauchamp and Thomas' (2009) claim that reflection on practice should be considered "as a key means by which teachers can become more in tune with their sense of self and with a deep understanding of how this self fits into a larger context which involve others; in other words, reflection is a factor in the shaping of identity" (p. 182). As a result, Maya now has the motivation to transform her identity and to identify a new 'possible self' in the sense of the "individual's ideas of what they might become, what they would like to become, and what they are afraid of becoming" (Stake, 2006, p. 954). She said, "engaging in self-evaluation activity made me realize that I was sometimes too judgmental to my students and unfriendly so that they seemed afraid of me. Actually, I don't want to be that kind of teacher. I want to be a friendlier teacher". This statement indicated that productive disruptions that emerged from the process of self-evaluation informed Maya that she was unfriendly and judgmental to the students. This 'actual self' encouraged her to make efforts to become a friendlier teacher, an 'ideal self' by changing her pedagogic disposition to formality/distance. In other words, the discrepancy between Maya's 'ideal self' and her 'actual self' provides a motivational push to change (Higgins, 1987).

In other words, Maya learned important things about herself and her teaching practice through their engagement in self-evaluation as a mediational activity. Self-evaluation is important as it enhances the likelihood of teachers' reflection by providing additional perspectives on themselves and on their teaching. As a result, Maya became more aware of the limitations of her practices.

Conducting self-evaluation enabled Maya to see herself differently. She did not realise that she was unfriendly towards and judgmental of the students. Additionally, teacher self-evaluation has helped Maya to recognise her teaching limitations. She became aware the need to praise the students more regularly, create a livelier classroom atmosphere, improve her classroom management skills, and establish a better relationship with the students. In sum, to become a more effective teacher, Maya needs to change her dominance and formality/distance practice.

In addition, Maya took the opportunity to learn from other teachers through collegial dialogues. Maya, in particular, shared her thoughts with her colleagues about monotonous nature of her teaching as a result of her dominance practice. From them, Maya then learned how to use new teaching techniques and a greater variety of teaching materials during her listening classes.

\section{CONCLUSIONS}

The findings demonstrated that the case study teacher was positive about her involvement in the series of teacher self-evaluation activities and she reported significant professional growth through her engagement in the self-evaluation activities. Additionally, the use of various mediational tools such as lesson video recordings, student feedback, and collegial dialogues to self-evaluate practice increased the teacher's understanding of her teaching. As a result, the teacher was able to effectively identify areas for improvement. This implies that the quality/nature of a mediation tool is important as it may make a significant contribution to the teacher's capacity to gain insights into the strengths and weaknesses of their teaching practices. The teacher, in turn, became more aware of the teaching actions in need of improvement, although these teachers individually experienced changes and improvement at varied levels. Hence, teacher self-evaluation is a powerful, productive, and promising method to support teacher professional development.

The findings also showed that self-evaluation mediated reflective practices which led to teaching improvement. Additionally, self-evaluation demonstrated the potential to generate the type of information required by teachers to perceive themselves differently and, in turn, these describe their possible-selves (Markus \& Nurius, 1986). As a result of self-evaluation, teachers were therefore able to identify whether or not their professional identity suited the context in which they operated. In this study, Maya altered her teaching identity: one from dominance to being more accommodating of the students' needs, and the others from being distant with the students to taking on a friendlier approach. Hence, the teacher self -evaluation activities provided the teachers with productive disruption in their understanding of their professional identity and teaching practices and, as a consequence, this created opportunities for the exploration of new and progressive teacher professional identities.

The findings also indicated that teacher self-evaluation provides teachers a voice and control over their own practice. They themselves explore their teaching to identify the possible issues that need be addressed so that "they devote greater energy to it than if someone else has chosen the issue" (Danielson \& McGreal, 2000, p. 31). Additionally, they have the autonomy to manage their evaluation of their teaching in ways that are suitable with their abilities and interests. This ownership of performance thus encourages teachers' awareness that they are responsible for and in control of the teaching and learning in their classroom.

Finally, this study has revealed that teacher self-evaluation leads to self-reflection through which teachers understand themselves better in terms of their strengths and areas for development. This reflection challenges teachers' normal thinking and perspective of themselves and their practice. This suggests that teacher self-evaluation contributes to professional learning by empowering teachers to transform their practice. Hence, it is necessary for both Indonesian 
universities and teachers to work together to successfully promote self-evaluation activity. Indonesian universities need to provide time, facilities and resources, and support for their teachers to engage in self-evaluation activity. Indonesian teachers are expected to have commitment to conduct self-evaluation to ensure the quality of their teaching, which in turn improve students' learning experiences.

\section{REFERENCES}

[1] Airasian, P. W., \& Gullickson, A. R. (1997). Teacher Self-Evaluation Tool Kit. Thousand Oaks, CA: Corwin Press.

[2] Beauchamp, C., \& Thomas, L. (2009). Understanding Teacher Identity: An Overview of Issues in the Literature and Implications for Teacher Education. Cambridge Journal of Education 39.2, 175-189

[3] Bjork, C. (2005). Indonesian Education: Teachers, Schools, and Central Bureaucracy. New York and London: Roudle.

[4] Chang, M. C., Shaeffer, S., Al-Samarrai, S., Ragatz, A. B., de Ree, J., \& Stevenson, R. (2014). Teacher Reform in Indonesia: The Role of Politics and Evidence in Policy Making. Washington DC: International Bank for Reconstruction and Development / The World Bank.

[5] Danielson, C., \& McGreal, T. L. (2000). Teacher Evaluation to Enhance Professional Practice. Alexandria: ASCD.

[6] Higgins, E. T. (1987). Self-Discrepancy: A Theory Relating Self and Affect. Psychological Review 94, 319-340.

[7] Johnson, K. E., \& Golombek, P. R. (2011). Research on Second Language Teacher Education: A Sociocultural Perspective on Professional Development. New York: Routledge.

[8] Lantolf, J. P., \& Thorne, S. L. (2006). Sociocultural Theory and the Genesis of L2 Development. Oxford: Oxford University Press.

[9] Limantoro, S. W. (2003). Teacher Self-Evaluation Models as Authentic Portfolio to Monitor Language Teachers' Performance. $K @ \operatorname{ta} 5.2,165-186$

[10] Markus, H., \& Nurius, P. (1986). Possible Selves. American Psychologist 41.9, 954-969.

[11] Mayer, D. (1999). Building Teaching Identities: Implications for Pre-Service Teacher Education. Paper presented at the Australian Association for Research in Education, Melbourne.

[12] Merriam, S. B. (2009). Qualitative Research: A Guide to Design and Implementation. San Fransisco: Jossey-Bass Inc.

[13] Richards, J. C., \& Lockhart, C. (1996). Reflective Teaching in Second Language Classrooms. New York: Cambridge University Press.

[14] Sinclair, J. M., \& Brazil. (1982). Teacher Talk. London: Oxford University Press.

[15] Stake. (2006). Multiple Case Study Analysis. New York: The Guilford Press.

[16] Taylor, L. (1994). Reflecting on Teaching: the Benefits of Self-evaluation. Assessment \& Evaluation in Higher Education 19(2). 109-122.

[17] Walsh, S. (2002). Construction or Obstruction: Teacher Talk and Learner Involvement in the EFL Classroom. Language Teaching Research 6, 3-23.

[18] Wesner, L. T. (2007). Another Way of Seeing: How Comparing Student Evaluation and Teacher Self-Evaluation in a High School Leads to More Reflective Teacher Practice. (Doctor of Education), Boston College, Boston.

Umi Tursini, Ph.D, is an English lecturer at the Faculty of Language and Literature, University of Kanjuruhan Malang, East Java, Indonesia. She earned his PhD from the University of New South Wales, Australia. Her research interests include teacher professional development, action research, and teaching speaking. 